\title{
Ethics and Moral Philosophy of Karol Wojtyla
}

Jove Jim S. Aguas

\begin{abstract}
Karol Wojtyla or John Paul II is more well known for his Papacy and for his teachings and writings as the Supreme Pontiff of the Roman Catholic Church for over a quarter of century. He wrote extensively about the dignity of the human person and defined the social doctrine of the Church. Through his encyclical letters, John Paul II affirmed the dignity of the human person more especially women and workers, and the importance of the family for the future of humanity. He was criticized for upholding the Church's teachings against artificial contraception and the ordination of women, the reform of the Liturgy and for his ecumenical efforts. Not much is known about the underlying thoughts of Wojtyla or John Paul II about ethics and morality which form as the basis of his papal teachings. This paper aims to elucidate on the thoughts of Wojtyla on ethics and ethical theory and his own brand of moral philosophy.
\end{abstract}

Keywords: Wojtyla, dignity of the human person, ethics, moral philosophy

\section{Ethics and Morality}

$\mathrm{M}$

an as a human being, is endowed with free will; through his free will, he determines his own actions; he is free to determine the course and the objective of his own actions and life. But free will comes with it responsibility. Since man is a free agent, he is responsible for his actions. However, his responsibility as free agent does not end with his own actions, he must also take responsibility for their consequences and for the quality of the choice that he makes. Every day, one is faced with situations where he has to make a choice, and it is one's moral obligation to make the right choice, to follow the good option from the variety of options at hand. Whatever one chooses and in whatever manner he chooses, he is responsible for that choice and for its consequences. The extent of one's knowledge and freedom determine the extent

(C) 2013 Jove Jim S. Aguas

http://www.kritike.org/journal/issue 12/aguas june2013.pdf

ISSN 1908-7330

(cc) BY-NO 
of one's responsibility. Hence, when there is greater freedom and knowledge, there is greater responsibility.

Freedom and responsibility are the concerns not only of philosophers; they are everybody's concerns. Because of human freedom and responsibility, people are always concerned with what is right and what is wrong. People contemplate on the right thing to do, and what is the bad thing to avoid. The purpose of all these considerations is the desire to live a well-lived life. Human beings do not just want to live their lives; they want to live life well, as the saying goes: a well-lived life is a happy life.

The rightness or wrongness, or the goodness or badness of an action, is the focal point of morality. Morality sets standards by which man can measure or judge whether an action is good or bad. However, there are those who view morality as a repressive institution, a set of rules which society and religion, parents and the like impose on man to prevent one from living his life the way one wanted it to be lived. To some extent, there is a grain of truth to this, but, that is insignificant as far as the real intention of morality is concerned. The fact that morality imposes certain "restrictions" does not make it repressive. Morality imposes on man certain rules or standards through which one determines what is right and what is wrong so that he can eventually shape his moral judgment and conduct. But the moral wisdom by which one judges an action, is not imposed on him by others, but by himself, in so far as he is committed to attain a kind of life that is well-lived. Morality, as a normative philosophy, offers a set of rules or standard according to which one has to conform his actions; these rules that one ought to follow. But then, as free agent man is free to follow rules or not, but one must not forget that as a free agent, he is responsible for his actions.

Before proceeding any further, morality and ethics must be properly defined. Morality applies only to human acts, that is, actions which proceed from man's rationality; these are actions which are done with knowledge, freedom and voluntariness. Actions which do not have a rational character can be considered amoral; they cannot be judged as morally good or morally evil. If human actions are to be judged whether morally good or morally evil, then there must be something by which actions could be measured as good or evil; this is what we refer to as the norm or standard of morality. The standard or norm does not only judge the morality of the action, it likewise gives the reasons why a particular action is morally good or morally evil.

The term "ethics" is commonly used interchangeably with "morals," hence, to be ethical is equated with being moral. Although there is an affinity between ethics and morals, it is more accurate to use the term morals to the act or conduct itself. The term ethics applies to the study of the morality of the act or conduct or the norms or codes that govern such conduct or act. The common denominator between the two concepts is the morality of the human act or 
conduct. The human act has a moral value, the value of being good or bad, right or wrong, and ethics studies the norms or standards or codes that would define or determine the morality of human act or conduct.

Ethics, which is also called moral philosophy, is motivated by the fact that people strive to be responsible agents of actions. Being responsible agents of actions starts with knowing which actions are good and which actions are bad. It is the role of moral philosophy or ethics to search for something that would guide man in determining what is good and right or bad and wrong. Ethics or moral philosophy as the study or science of the morality of human acts, deals with the issue whether an action is good or bad and the reasons why a particular action is good or bad. Hence, it is the concern of moral philosophy not only to say that abortion is evil, but also to give the reasons why it is evil. Ethics as a philosophy is the attempt to achieve a systematic understanding of the nature of morality and what it requires of man - how man ought to live and why. Ethicists or moral philosophers are not only concerned with the morality of human actions, they are also concerned with the reason why an action is moral or immoral. They offer a wide variety of norms or standards by which one can judge whether a particular action is good or evil.

If one is to make moral judgments, he must back them up with valid reasons. Although some people rely on feelings and emotions as basis on moral judgment, such is not acceptable, because emotions or feelings are usually biased, irrational or are just products of one's prejudice, and social and cultural conditioning. It one wants to discover the truth, he must try to let his feelings and emotions be guided by reason. It is this search for moral wisdom that has led moral philosophers to investigate and study different topics and issues on morality.

Ethical theories are the set of principles or rules that serve as the basis in determining the morality of human actions or conduct. Men use or rely on them in making moral judgment; they also provide the reasons why a particular action or behavior is good or bad; acceptable on unacceptable. Ethical theories abound, many of them claim to be the better theories than others, if the not the most appropriate. Other theories are normative, proposing certain standards or norms of ethics, while others are descriptive, offering an account of ethical experience. Some are based on reason and proposed formal rules or imperatives. Others are based on sentiments and emotion and proposed certain values as the standards of morality. Others are highly abstract and speculative while others are situational which means that they ground ethics on experience. Ethical theories are often polarized into the rational and the experiential. The rational is sometimes further divided into the intellectual and volitional and the experiential is sometimes also distinguished into the sentimental and perceptual. It is not the concern of this study to classify ethical theories. 


\section{Wojtyla's Ethics in General and Analysis of the Ethical Act}

Wojtyla's account of ethics is just one of the many theories. In his account of ethics he attempts to integrate the rational and experiential elements of the ethical act. He is critical of certain formal and emotive ethics; he particularly criticizes the formal ethics of Kant and the emotive ethics of Scheler. His ethics is grounded on Thomistic ethics, having been influences by the philosophy of St. Thomas. However, he is also influenced by phenomenology, and through his own application of phenomenology, he also integrates experience into his analysis of ethics.

There are two concerns that need to be addressed: the first is Wojtyla's analysis of the ethical act and focus on the role of experience, will and reason. This can be considered as the part of his philosophy which deals with ethical theory. The second is what can be considered as the moral part of his philosophy. The focus will be on his notion of efficacy, transcendence and self-determination, truthfulness and conscience. These concepts may be correlated with the notions of value, truth and good as essential components of an ethical theory.

Woityla's ethical theory is based on a critique of Schelerian and Kantian ethics and an appropriation of Thomistic ethics. He analyzes the ethical positions of Scheler and Kant and offers his own way of doing philosophy of ethics along Thomistic lines. The bedrock of his ethics is the act of the will which is grounded on the experience of efficacy. But the object of the will is the good which must be a perceived as a value by the person. In the course of this discussion, experience, which should be the starting point of ethics, will be correlated with the good, which is the object of the will, and the truth, which is the object of reason and must be a quality of the good that is desired by the will. Wojtyla's moral philosophy is based on his notion of the human act, an act which manifests efficacy, transcendence, self-determination and self-fulfillment. The morality of the act must be based on goodness and truthfulness. Human actions are affected by one's conscience and determined by freedom and carries with it responsibility.

Wojtyla's dissertation in philosophy is a critical exposition of the ethics of Scheler. Although he rejects the ethics of Scheler, he looks at Scheler as a possible guide for searching for answers about ethics and values; answers to questions like "Why be good?" The work of Scheler opens up a new world, a world of values, fresh view of mankind. ${ }^{1}$ With a solid background in Thomism, Wojtyla is open to engage modern philosophy on its own terms and the outcome would be, what Wojtyla would regard years later, as a way of doing philosophy that synthesized the approaches of metaphysical realism of Aristotle and Thomas Aquinas and the

\footnotetext{
${ }^{1}$ George Huntston Williams, The Mind of John Paul IL Origins of His Thoughts and Actions (New York: The Seabury Press, 1981), 115.
}

(c) 2013 Jove Jim S. Aguas http://www.kritike.org/journal/issue 12/aguas june2013.pdf ISSN 1908-7330 
sensitivity to human experience of Max Scheler's phenomenology. ${ }^{2}$ It is Scheler's personalism which rescues moral philosophy from the dry abstractions of Kantian ethics and restores the pathos, ecstasy, and ethos to human life, that Wojtyla finds most attractive. ${ }^{3}$

Phenomenology develops a system of disencumbering the mind of all philosophical and other presuppositions. It is confident that, by the process of intellection ("bracketing" and "reduction"), the mind, whether the intellect or will or feeling (as in the case of Scheler), could at least sufficiently comprehend the most important aspect of reality, namely, its essence. It further seeks to develop a methodology for mirroring a given reality in its essence and making it possible to presume its existence. Against this Scheler brand of phenomenology, Wojtyla argues a number of points in order to uphold traditional Catholic ethics against a "new kind of allegedly objective experiential subjectivism." ${ }^{4}$ Wojtyla observes that in Christian ethics there is the ideal of moral perfection, the truly perfect person (Jesus Christ and the evangelical saints and saints of the Tradition). In these persons, the ideal is embodied and the values are practiced. The ideal is presented as an obligation in commandments and counsels; the saintly person becomes a model for imitation. ${ }^{5}$

Scheler, with his brand of phenomenology, is so important in the development of the thought of Wojtyla, especially because of the fact that Wojtyla wants to insist on making revealed ethics constitutive of perennial ethics. Although in the end Wojtyla rejects Scheler's system of ethics, in effect, Scheler introduces Wojtyla into the phenomenological method of grasping the circumstances of the ethically positive or negative as they are lived through in experience.

\section{The Role of Experience in the Analysis of the Ethical Act}

According to Wojtyla, every human action involves a particular lived experience which he refers to as ethical experience. ${ }^{6}$ Lived experience is the awareness on the part of the individual that when he performs or does a certain action, he is aware that he is the author of the act; that he is the agent of action. This awareness or experience brings with it a sense of responsibility for the moral value of the action. Since one experiences himself and his own person as the agent

\footnotetext{
${ }^{2}$ Ibid.

${ }^{3}$ Rocco Buttiglione, Karol Wojtyla: The Thoughts of the Man Who Became Pope John Paul II (Grand Rapids Michigan: WB. Eerdams Publishing Co., 1997), 54.

${ }^{4}$ Williams, 117.

${ }^{5}$ Cf. Ibid.

${ }^{6}$ Karol Wojtyla, "The Problem of the Separation of Experience from the Act in Ethics" in Person and Community: Selected Essays, trans. by Theresa Sandok, OSM (New York: Peter Lang, 1993), 23.
}

(C) 2013 Jove Jim S. Aguas http://www.kritike.org/journal/issue 12/aguas june2013.pdf ISSN 1908-7330 
or cause of the act, then he also experiences himself as the efficient cause of the moral good or evil associated with the action. Through this, he also experiences the moral good or evil of his own person. Hence there is a kind of lived experience that is associated with the moral value of the action, and this Wojtyla calls ethical experience. Lived experience, which is a notion common in phenomenology and existentialism, is quite a complex concept. How can it be properly interpreted? Wojtyla cites the studies of Narziss Ach, Albert Michotte and the psychologists of the school of contemporary experimental psychology of the will. ${ }^{7}$ These studies provide a modern tool for reflecting on ethical experience based on empiricalinductive method.

The proper interpretation of lived experience has always been one of the tasks of ethicists. Ach and his colleagues, provide the ethicists with the proper interpretation of lived experience. Furthermore, through these studies, Wojtyla sees the connection between lived experience and the act of the will. In the lived experience, that is, in one's experience of himself as efficient cause of his acts, one encounters immediately the will. Wojtyla stresses, that in the lived experience, there is definitely an ethical experience and the deeper understanding of the nature of the will can be achieved only by a thorough analysis of ethical experience. ${ }^{8}$ He is convinced that "ethical experience implies a lived experience of the efficacy of the person, an experience in which the will manifests itself phenomenologically as a basic structural element of the whole empirical fact." ${ }^{\prime \prime}$ On the basis that lived experience has a real empirical character and an empirical fact, Wojtyla concludes that ethics is a science and that ethics cannot be divorced from experience, specifically lived experience.

But how can experience be properly related to ethics? Wojtyla first analyzes Kant's position on this question. According to him, Kant's approach to ethics results in a distinction between two elements of ethical life. The first is the a priori rational element which is expressed in the categorical imperative, and the other is the experience that takes the form of the feeling of respect for the law. ${ }^{10}$ But Wojtyla argues that Kant's critical approach to ethics split the unified content of ethics reducing it to two separate modes of investigation, namely, logical and psychological. He further stresses that such dichotomy is against experience for the facts of ethical life cannot be reduced to logic and psychology, because of the fact that an ethical experience is a personal whole. A specific element of the ethical experience ceases to be itself once it is separated from the whole. One example of this is the ethical experience of duty which is conceived by Kant as merely the feeling of respect for the law. Wojtyla also analyzes Scheler's concept of ethical

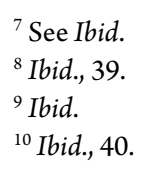


experience of a value. Value for Scheler is an objective content felt by the person. But according to Wojtyla, value is primarily a work of the person and brought about causally in the individual's personal essence. ${ }^{11}$

\section{The Role of Will and Efficacy in Ethical Act}

Wojtyla contends that the person is the efficient cause of his action. Experience, upon which ethics is based, reveals that the person experiences himself or is aware of himself as the efficient cause of his action. The person experiences himself as the subject of ethical values, namely the moral good and evil. Consequently, Wojtyla relates ethical experience to efficacy. He says: "Ethical experience is contained immanently in every human activity in which the personal self is conscious of its efficacy." ${ }^{12}$ Ethical experience is contained in the act of the will itself not in something outside of the will, like feeling, as Scheler suggested. The "lived experience of responsibility points to the will as the psychological factor that constitutes the very core of ethical experience."13

For Scheler, according to Wojtyla's analysis, ethical experience is contained in the emotion. The very core of ethical experience for Scheler is not the efficacy of the person but the emotional experience of the value. This is the essence of Scheler's emotionalism, which is the basis of his ethical theory based on values. According the Wojtyla this completely disregards the efficacy of the person. Kantian ethics on the other hand, also fails to acknowledge the efficient and dynamic moment of the will. Despite Kant's view of the will which he developed in his Critique of Practical Reason, his analysis could be reducible to practical reason and its imperatives. Kantian imperatives or maxims and Schelerian values are aphorisms and neither of them objectify the dynamic factor of action which is fundamental for ethics. Action according to Wojtyla is the locus of authentic ethical experience. Aphorisms in this context are antithetical to experience and if ethics is to be related to experience it must be free from such kinds of aphorisms.

Wojtyla asserts that when we take as our starting point the inner experience of efficacy which is rooted in the personal self and manifests itself in the act of the will we grasp correctly the balance between motivation and action in the act of willing. This is because a motive has meaning only in relations to the act of the will that it motivates. Any analysis of motives, whether in the form of

\footnotetext{
${ }^{11} \mathrm{Ibid}$.

${ }^{12}$ Karol Wojtyla, "The Will in the Analysis of the Ethical Act" in Person and Community: Selected Essays, trans. by Theresa Sandok, OSM (New York: Peter Lang, 1993), 8.

${ }^{13}$ Ibid., p. 9.

(c) 2013 Jove Jim S. Aguas

http://www.kritike.org/journal/issue 12/aguas june2013.pdf

ISSN 1908-7330 
maxims or values, that fails to consider the act of the will distorts the essence of the motives. ${ }^{14}$

In his analysis of the act of the will, Wojtyla follows the conception of St. Thomas about the act of the will. For St. Thomas, the act of the will has two basic sources of actualization: one is the nature of the will itself as an appetite or an inclination, and the second is the objectification of the goodness of an object by reason. In the first actualization, the will, which is an appetite in itself, manifests a natural inclination toward anything that is in any way good. The will has a natural inclination toward anything perceived to be good, like food, relaxation, education, friends, love ones, etc. Hence, the will is in itself a causal-efficient source of impulses in the human being. But the will is also a rational faculty, it is a rational appetite and the will's natural rationality of desire is actualized when the will conforms its motions or choices to reason's judgment about the object of desire. The true goodness of the object of the will as evaluated by reason directs the inclination of the will. Hence the will is actualized by the true good as assessed by reason. The various objects of the will are goods objectified by reason and the will is in potency with respect to the good and the potency of the will towards these goods is actualized by reason. Hence reason has crucial role in the ethical act.

\section{The Role of Reason in the Ethical Act}

Reason and will are the two rational faculties of man, and they constantly work hand in hand. The will wills so that reason may know, and reason knows so that the will wills what it wills. The object of the will is the good and the object of reason is the truth. The will naturally inclines to the good and reason apprehends the truth. It is the task of reason to apprehend or objectify the good. The result of this close interaction of the reason and will is that, the true and the good, in some sense mutually permeates each other. The true known by reason is good, and the good willed by will is true. Although reason apprehends the good in a speculative way when it defines the good's essence, and since the good is an object of action, then, reason apprehends the good from the aspect of action. Reason also distinguishes among the different kinds of goods, namely: bonum honestum, bonum utile and bonum delectabile. Bonum honestum refers to the good that conforms to the nature of a rational being because it is in keeping with the what that being desires for itself, bonum utile is a good that is a means to an end, bonum delectabile is the subjective good of satisfaction or pleasure.

Through these distinctions, reason guides our action. Following St. Thomas, Wojtyla stresses the directive role of reason in human action. Such directive role of reason in action is determined mainly by a holistic view of the

${ }^{14}$ See Ibid., 10-11. 
human being, a part or faculty of which, is reason. Reason is part of the whole human person and performs its practical functions within this whole. ${ }^{15}$ The superior and directive character of the function of reason is determined in a fundamental way by the fact that reason defines the good, which is the end of the human being and his action - the bonum honestum. This, according to Woityla, is what guarantees that reason has a directive role in human life. Reason sees to it that the good desired by the will is the real and true good and not just a delectable or useful good. Even the value perceived by the will must be a real and true value of the object which is desired by the will. Following St. Thomas again Wojtyla asserts:

The moral life consists in attaining the truth in all our action and behavior, and activity by nature always aims at some good. Consequently the essence of moral life is the lived experience of the truth of the good realized in action and the realization in that action of the good subjected to the criterion of reason and thus placed in the light of that truth. ${ }^{16}$

\section{The Function of Norms in Ethical Theory}

One of the tasks of an ethical theory or a theory of morality is to objectify or apprehend the content of the experience of morality. The experience of morality or the ethical experience is always subjective; our experience of moral value, that is, good and evil, always happen in the subjective context; experience is always subjective because it is the human subject who experiences. The task of a theory of morality according to Wojtyla is to transpose this content, that is, our experience of moral value into the theoretical or objective, so that we can fully understand the meaning of such moral value. This task of objectifying the moral value is possible through norms, because it is through norms that moral values are evaluated. The norms are the basis of moral value, they serve as the standard or basis for saying whether an object has a good value or not. Moral value cannot be objectified without norms; without the norms moral values will remain subjective contents of ethical experience. Without the norms we cannot objectify the moral value and consequently we cannot have a theory of ethics or morality. For example, because of the norm of truthfulness, we differentiate the good of telling the truth and the evil of telling lies. Wojtyla writes:

15 Karol Wojtyla, "The Role of Reason in Ethics," in Person and Community: Selected Essays trans. by Theresa Sandok, OSM (New York: Peter Lang, 1993), 67.

${ }^{16}$ Karol Wojtyla, "The Basis of the Moral Norm" in Person and Community: Selected Essays trans. by Theresa Sandok, OSM (New York: Peter Lang, 1993), 91.

(c) 2013 Jove Jim S. Aguas

http://www.kritike.org/journal/issue_12/aguas june2013.pdf

ISSN 1908-7330 
Characteristic of moral value is that it arises in the form or good and evil, a division that has both its objective and subjective source in norms. Not only are norms the basis of moral value, but they are also the source of the division of good and evil of the whole sphere known as moral value. ${ }^{17}$

Furthermore, Wojtyla asserts that the relation between the moral value of good and evil and the norm of morality determines the essential structure of every moral fact. Norm as the basis of moral value is the more profound and fundamental expression of morality because the distinction between good and evil is based and dependent on a norm. ${ }^{18}$ The task of the theory of morality of objectifying the content of ethical experience as adequately as possible would not be achieved without norms. Hence, while Scheler points to value as the basis of morality, which he considers to be objective and a priori, Wojtyla argues that norm and not value is the objective basis of moral value and consequently of morality.

\section{The Meaning of Moral Value}

Moral value shows the axiological dimension of morality and it basically corresponds to an experience and this makes it the most obvious feature of morality. Through moral value, action and the people who perform them, manifest certain distinct quality: virtuous, sinful, just, kind, cruel, bad, etc. For Wojtyla, the proper and adequate interpretation of moral value must be apprehended in the context of the being and becoming of the human being through his action. Through the act, a human being becomes morally good or evil depending on whether the act is good or evil. ${ }^{19}$ When one helps the poor, he becomes morally good and when he cheats in his obligation, he becomes morally evil. Of course, this does not mean that when one does an evil act he becomes evil per. Moral value cannot be interpreted only on the basis of the subjective (or emotional) experience of the value, because in addition to the subjective experience, the experience of morality also reveals also the efficacy of the human being. ${ }^{20}$ The human being becomes morally good or evil by virtue of his efficient involvement in the experience. The human being as a person becomes a morally

\footnotetext{
${ }^{17}$ Karol Wojtyla, "The Problem of the Theory of Morality" in Person and Community: Selected Essays trans. by Theresa Sandok, OSM (New York: Peter Lang, 1993), 135.

${ }^{18}$ Ibid.

${ }^{19}$ Ibid., 143.

${ }^{20}$ Ibid. 
good person through his morally good action and conversely a morally evil person through his morally evil action.

One interpretation of moral value is to regard it as an end; this interpretation characterizes morality as teleological. But in what sense can we interpret moral value as an end? An end is always understood as the object of an aim. And it cannot be denied that people do not only aim at goods, they also want to be good. This wanting to be good is also at the core of morality. The realization of the moral good maybe different from the other objective values of the person, but the striving for moral value pervades all other wanting of other goods, because in wanting other goods, one also wants to be good himself. There are therefore two strivings and two senses of values: first, there is the striving or wanting of objective goods, and second there is the striving for the good of oneself; there is the wanting of a good and the wanting to be good. In wanting any good, the subject, that is the person, goes out toward a valuable object and in wanting to be good, he confers value upon himself. ${ }^{21}$ This for Wojtyla is a distinctive teleology of morality.

Moral value as an end, when applied to the human person takes a different connotation; as an end, it is not only the object of a particular aim, it adds up to the fulfillment of the person and the action. When an act is good it adds up to the fulfillment of the person. Wojtyla says:

... moral value determines the fulfillment of actions proper to persons and also determines the fulfillment of the persons themselves in such actions. In acting, we either fulfill ourselves or do not fulfill ourselves. This depends precisely on moral value. Moral good is that through which we fulfill ourselves in action and evil the opposite. ${ }^{22}$

Now, if one wants to be good, then he must be good. This is where the element of duty is connected to moral value. In lived experience, the wanting of certain objective value involves a necessary factor in the essence of morality, the element of duty. One essential feature of duty is the lived experience "I must." This is a kind of "inner coercion that constitutes a distinctive modification of the experience "I want." ${ }^{23}$ Wojtyla further explains that the "I must" and the "I want" are both inner coercion that arise from one's own self, but they differ not just in the intensity of striving but also in the kind of value attached to them. In moral

${ }^{21}$ Karol Wojtyla, The Acting Person translation of the Polish Osoba $i$ Czyn by Andrzej Potocki (Dordrecht, Holland; Boston, USA; London, England: D. Reidel Publishing Co., 1979), 148. (Henceforth AP)

${ }^{22}$ Ibid., 149.

${ }^{23} \mathrm{Ibid} ., 152$.

(c) 2013 Jove Jim S. Aguas

http://www.kritike.org/journal/issue 12/aguas june2013.pdf

ISSN 1908-7330 
duty there is an unconditional value attached to it. When one say "I must do this" there is no ulterior condition or other motive attached to it. Moral duty signifies the unconditionality of the moral value or of the good. In this sense duty is more decisive for morality than value. Wojtyla further writes:

Moral duty as a lived experience reflects in a way the whole system in which good and evil mutually oppose and mutually exclude one another - and this is what accounts for that distinctive unconditionality which encompasses within its scope both the moral value contained in a concrete action and the objective values toward which that action is directed. ${ }^{24}$

\section{The Experience of Efficacy}

In the distinction he makes between the two operations or dynamisms in man, namely: acting and happening, Wojtyla introduces the basis of this differentiation as the "experience of efficacy" or "moment of efficacy." This notion is understood as "having of the experience of being the actor;" in other words man experiences himself as the agent, and origin of his actions. This is a lived experience. When man acts, he experiences himself as the cause of his actions; he knows that it is he who brings the action into existence and sustains its existence. By experiencing himself as the efficient cause of the action, "man discovers that he is completely immanent in the action and simultaneously transcends it." ${ }^{25}$ In "happening," on the other hand, there is no efficacious participation of man. Although the function happens in him, he does not really consciously bring it to existence. Wojtyla writes:

This experience discriminates man's acting from everything that merely happens in him.... When acting I have the experience of myself as the agent responsible for this particular form of dynamization of myself as the subject. When there is something happening to me, then the dynamism is imparted without the efficacious participation of my ego. ${ }^{26}$

Wojtyla calls those dynamisms in which man is not active as the concrete and efficacious ego, as activation. "There is activation whenever something

\footnotetext{
${ }^{24}$ Ibid.

${ }^{25}$ Buttiglione, 135.

${ }^{26}$ Wojtyla, AP, 66.
} 
happens only in man and the something that happens is derived from the inner dynamism of man himself." ${ }^{\prime 7}$ Hence, the concept of efficacy leads us to the subject or the person as the ontological structure or basis of action. The concept of efficacy establishes the causal relation between the person and action. The person as the agent of the action is the cause of such action; his actions in effect are his property.

\section{The Act of Volition}

Human action is related to the act of willing or volition. In the act of willing or volition, the self directs itself to an external object. Willing is an intentional act of the person, in such act, he orients and directs itself to an object outside of himself. The object of any intentional act is so to speak outside or external to the person and the person directs his attention to the intended object. In volition the will directs its attention towards a desirable object, with its own intentional acts; it can direct its attention to objects either as an end or value, and this is manifested in the expression, "I will something." In the intentional act, the human subject aside from being oriented or directed outward toward an object, somehow extends beyond its own limit, so the limits of the person are somewhat overstepped. ${ }^{28}$ This stepping out of the limits of the person towards the external object is what Wojtyla refers to as "transcendence."29 In willing or volition, this transgression of the limits in the direction of the object is what Wojtyla calls, "horizontal transcendence." "Such an active directing.... also implies the transcendence of this subject toward the value and end; the subject actively goes out beyond itself toward the value." ${ }^{30}$ In horizontal transcendence, the person crosses its own boundary towards the valued object.

In willing, the person never passively directs itself to an object; when one wills something, he moves toward the object, toward whatever is willed. ${ }^{31}$ However, this does not mean that the person is absorbed by the object; the innerness of the person is never dominated by the outerness of the object. Wojtyla explains, "the object... never leads the subject back upon itself; it never forces the subject into its own reality thereby determining from without." ${ }^{32}$ Because of this subject-object relation determinism is never possible, because it is

${ }^{27}$ Ibid., 69.

${ }^{28}$ Wojtyla, $A P, 126$.

${ }^{29}$ Etymologically, the term "transcendence" means to go over or beyond a boundary or a threshold.

${ }^{30}$ Karol Wojtyla, "Personal Structure of Self-Determination" in Person and Community: Selected Essays trans. by Theresa Sandok, OSM (New York: Peter Lang, 1993), 147.

${ }^{31}$ See a similar discussion in Buttiglione, 146.

${ }^{32}$ Wojtyla, $A P, 127$. 
the person as the efficacious self that determines, possesses and governs itself and not the willed object.

It was previously discussed that willing something is always directed toward an appropriate object which may be a good or a value. The greater the good or the value, the greater is its power to attract the will and consequently the person. The person's predisposition to be attracted by the positive and authentic goods and values, his unreserved consent to be drawn in and absorbed by them are crucial factors in determining the maturity and the perfection of the person. ${ }^{33}$ Hence, the moment of decision and choice are essential parts of willing; they define the intrinsic essence of volition as intentional acts whether one simply wants or wills something or chooses something over another object.

Wojtyla characterizes decision is a crucial constitutive moment in the experience of self-determination; it is always directed toward a value and involves the readiness to strive toward the good. It is viewed as an instance of threshold that the person has to pass on his way toward the good. His decision is somehow influenced by his absorption of the good and is further augmented as he approaches the good. The more he is attracted to the good, the more decisive his actions become. This shows the dynamism of the person as he strives towards the good, transgressing his own boundaries.

Now, motives have certainly an effect on one's willing more particularly on the intentionality of the will, this effect of motives to one's willing is referred to as motivation. When one wants something, the object presents itself to his attention as a good and manifests its value. This presentation of values which corresponds to his cognition of the values is followed by the movement of the will toward the object presented as good. This outright movement is due to his motive without which there would be no tending toward the value. Wojtyla clarifies: "To will means to strive after a value that thereby becomes an end." ${ }^{34}$ It is motivation that leads the will out of its initial indetermination. It is motivation that initiates the action of man, without motivation man would not move out of indetermination.

Decision is more fully manifested in choice rather than in simple willing because in choosing the subject manifests his self-determination, his freedom. Wojtyla points out, that freedom is present and manifests itself in the ability to choose. This ability to choose "confirms the independence of the will in the intentional order of willing. In choosing, the will is not cramped by the object, by the value as its end; it is the will and only the will that determines the object." ${ }^{35}$ Freedom then, is both dependence and independence; it is dependent on the self

\footnotetext{
${ }^{33} \mathrm{Ibid}$.

${ }^{34}$ Ibid., 129.

${ }^{35}$ Ibid., 132.
} 
because it is the self through the will that decides, and independent from objects since when the self decides it is never determined by the object.

\section{The Reference to the Truth}

Is it possible to choose anything we want, can we decide on any matter we perceive to be good? Previously, the role of reason in ethics has been discussed, and its role is anchored on the truth. While reason is oriented to the truth, the will as a faculty of choice is oriented towards the good. For Wojtyla, however, choice is not an arbitrary shooting in the dark, but a deliberate selecting. The ability to decide and to choose is connected with another significant trait in the dynamism of the will, that is, the reference to "truth." Reason has a role in determining the truth of the good that the will desires. He explains:

The reference to truth forms an intrinsic part of the very nature of a decision and is in a special manner manifest in choice. The essential condition of choice and of the ability to make a choice as such, seems to lie in the specific reference of will to truth, the reference that permeates the intentionality of willing and constitutes what is somehow the inner principle of volition. ${ }^{36}$

Truth, Wojtyla asserts, is what releases the will from determination by the object and enables the person precisely to be self-determining in his acts with respect to all possible objects. This is so because the objects presented to the person who makes the choice are presented through cognition, and cognition is itself focused on truth. Objects of choice do not come to the person as forces or impulses that push him into action, as it were. This would mean bypassing the will and making the choice determined by the object and not determined by the person. On the contrary, objects come to the person as things with a determinate known value that can be compared with other things according to that same known value. So the cognized truth of the object, mediates the object and the will so that values do not compel but are freely responded to by the will.

While it is through cognition that the truth is known, it is the will that responds to truth. The will itself in its own structure, wants the truth in what it wills or wants. The will wants true goods, not things that appear to be good and are really not. Wojtyla stresses that to "choose" does not simply mean turning toward one value and away from others, it means making a decision, according to the principle of truth, upon selecting between possible objects that have been

${ }^{36}$ Ibid., 137.

(C) 2013 Jove Jim S. Aguas

http://www.kritike.org/journal/issue 12/aguas june2013.pdf

ISSN 1908-7330 
presented to the will. ${ }^{37}$ The orientation to truth is essential to the will and to its power of self-determination. The recognition of the validity and truth of the intended object is part of the dynamism of the will because choice and decision are preconditioned by knowledge of the truth. Knowledge then is the condition that not only enables but also influences choice, decision making, and more generally the exercise of self-determination. ${ }^{38}$

Wojtyla makes the will's reference to the truth as the inner principle of decision and choice. Truth in cognition and the intrinsic orientation to truth in the will are what make freedom and choice possible. ${ }^{39}$ In every volition, what is manifested is a specific dependence, a specific moment of "surrender to truth" even before the object is presented to the will for decision and choice. It is because of this surrender to the truth that the person becomes independent of the objects of his own acting through the moment of truth; this moment of surrender to the truth is contained in every authentic choice of decision making. ${ }^{40}$

The moment of truth must be distinguished from the truthfulness of the particular choices and decisions that may be actually made. Wojtyla points out that one can err in judgment and he can choose against the truth of the good. Intellectual error and bad choice are facts manifest to experience, and defects manifest to experience too. A striking sign of this is the experience of sin and guilt which are not merely error and the consciousness of error in judgment (such error could be involuntary); they are also error and the consciousness of error in choice (such error has to be voluntary because it is internal to the choosing). But there cannot be error, or any consciousness of error, without a truth by which to judge error and, moreover, without an intrinsic ordination to and desire for truth in cognition and choice. Erroneous choice would not be sin and would not lead to guilt if error were not somehow a defect, a distortion, within the structure of choice itself and were not experienced as such. The phenomenon of choosing, of self-determination, and of guilt and sin and their opposites, are direct personal experiences of the inherence of truth in the structure of "I act."

\section{The Role of Conscience}

It is in conscience that the truth presents itself as the source of moral duty, a sort of a "categorical imperative." Wojtyla argues that the proper place of

${ }^{37} \mathrm{Ibid}$.

${ }^{38} \mathrm{Ibid}$., 140. "Knowledge is therefore a condition of the will. It is impossible to turn to values without knowing them. Knowledge of the truth about the object toward which the will is oriented is a fundamental part of the experience of value." Buttiglione, 147.

${ }^{39}$ Peter Simpson, On Karol Wojtyla (Belmont CA: Wadsworth/Thomson Learning, 2001), 28-29.

${ }^{40}$ Wojtyla, $A P, 138$.

(C) 2013 Jove Jim S. Aguas

http://www.kritike.org/journal/issue 12/aguas june2013.pdf

ISSN 1908-7330 
the subordination of the good to the truth is conscience, where the authentic transcendence of the person in action is realized. In conscience, the human act becomes the willing and choosing of a "true good." ${ }^{\text {41 }}$ It is conscience, through its first principle: "do good and avoid evil," that directs the person to choose and will the good. Conscience directs the person towards the truth and in the direction of a good willed and chosen in the light of truth. ${ }^{42}$ Through this direction and admonition of conscience, the person achieves self-fulfillment by transcending the limitations of the self and willing the real good chosen in the light of truth.

Conscience however, should be based on truthfulness. Responsibility is basically founded on freedom, but for Wojtyla the source of responsibility is more than freedom but the sense of duty. This is the connection of the anthropology of Wojtyla to his ethics and axiology. When conscience passes a judgment on an act, it does so in the sphere of moral values. According to Wojtyla, conscience maybe considered as a distinctive system, and as such, "it consists in a very specific effort of the person aimed at grasping the truth in the sphere of values, first of all in the sphere of moral values." ${ }^{\prime 3}$ At first it inquires into the truth, then establishes certitude and passes a judgment, so conscience has a specific role in evaluating and recognizing that true moral good. Wojtyla recognizes that conscience may falter in this effort and maybe in disaccord with the reality of the good. Given this, it is important that conscience be closely related to truthfulness. The effort of conscience to be truthful is closely connected with the will, particularly with selfdetermination. The will strives towards good values and this striving is closely related to the effort of conscience to be truthful. Wojtyla states:

Truthfulness, seen as the normative rule of truth put to exercise by the conscience, is like the keystone of the whole structure. Without truthfulness (or while out of touch with it) the conscience or, more broadly speaking, the whole specific system of the moral function and order cannot be properly grasped and correctly interpreted. ${ }^{44}$

Moral truthfulness however, is not enough; it is not enough that we know the moral truthfulness or falsity of normative propositions, it is not enough that we can approximately say that "being honest is morally good" or that "lying is morally evil." There should be a transition from "being honest is morally good" to "I should be honest," from "lying is morally evil" to "I should avoid lying." This is

${ }^{41}$ Karol Wojtyla, "Person, Subject and Community" in Person and Community: Selected Essays trans. by Theresa Sandok, OSM (New York: Peter Lang, 1993), 234. (Henceforth PSC)

${ }^{42}$ Ibid.

${ }^{43}$ Ibid., 160.

${ }^{44} \mathrm{Ibid}$. 
where the normative power of truth lies, in the transition from the "be" to the "should;" this is where duty lies. Conscience according to Wojtyla is where we achieve "the peculiar union of moral truthfulness and duty which manifests itself as the normative power of truth." ${ }^{45}$ Wojtyla explains:

The explanation of the normative power of truth is to be sought in its reference to the sense of duty, while it also explains the sense of duty because of the reference to values. The fact that the assertion " $\mathrm{X}$ is truly good" activates the conscience and thus sets off what is like an inner obligation or command to perform the action that leads to the realization of $\mathrm{X}$ is most strictly related with the specific dynamism of the fulfillment of the personal ego in and through the action. ${ }^{46}$

Wojtyla stresses that the sense of duty is the experiential form of the dependence on the moral truth, to which the freedom of the person is subordinate. The role of conscience is to experience not only truthfulness but also duty, and duty relies on moral truthfulness. It is not the function of conscience to create norms, but rather to discover these norms. There are moments however, when these norms and conscience are far apart and seemingly contradict each other. But Wojtyla explains that this does not mean that these norms are external or foreign to conscience. Because of the moment of truth, conscience is ordered to truth and consequently recognizes these norms as its own. Truth relieves the tension that may arise between the objective order of norms and the inner freedom of the person, once the norms are acknowledged by conscience as true, they are no longer external to it; these norms are then freely accepted by the person. ${ }^{47}$

Wojtyla clarifies that the fundamental value of norms lies in the truthfulness of the good they objectify and not in the generation itself of duties. While we can speak of the truthfulness of conscience which is subjective, we also have to consider the objective truthfulness of norms and the objective truthfulness of good that they objectify. "The positing of norms arises in the form of judgments, but these judgments always presuppose a general concept of good. This concept encompasses the whole world of goods in their analogousness: it

\footnotetext{
${ }^{45}$ Ibid., 162.

${ }^{46}$ Ibid., 163.

${ }^{47}$ Ibid., 166.
}

(C) 2013 Jove Jim S. Aguas http://www.kritike.org/journal/issue 12/aguas june2013.pdf ISSN 1908-7330 
includes all the good in every respect $\ldots{ }^{48}$ Obligations and duties must be grounded on objective moral norms which are based on the truth of the good. But to really have a normative power, the truthfulness of norms must be experienced by the subject.

In connecting this to man's moral life Wojtyla, following the thought of St. Thomas, says: "the essence of moral life is the "lived experience" of the truth of the good realized in action and the realization in that action of the good subjected to the criterion of reason and thus placed in the light of truth." ${ }^{\prime 9}$ Wojtyla further stresses that duty is a specific interpersonal reality due to the fact that man has an inherent obligation to all other people. "There is a correlation between the conscience as the interpersonal source of duties and the objective order of moral or legal norms, the order that in its significance and application extends far beyond an individual person and his concrete innerness." ${ }^{50}$

Conscience, Wojtyla says, is not just a passive acknowledgement of norms as if these norms are forced upon it and by compulsion conscience simply subscribe to it. It is rather creative but it does not compromise truth and its capacity for truthfulness.

Conscience plays a creative role in what concerns the truthfulness of norms, that is to say, of those principles of acting and behavior which form the objective core of morality or law. Its creativity goes beyond simple recognition of the norm or injunction that generates the sense of obligation resulting in passive obedience. ${ }^{51}$

The experience of rightness is preceded and integrated by the experience of truthfulness. The latter inheres in the acceptance of a norm which is caused by the strength of the subjective conviction. The creative role of the conscience coincides with the dimension of the person; it is wholly internal and applies to the acting, as well as to the moment of the person's fulfillment of himself. Woityla emphasizes:

Indeed the creative role of the conscience consists in the fact that it shapes the norms into that unique and unparalleled form they acquire within the experience and fulfillment of the person. The sense of conviction and certitude, whereby the truthfulness of a norm is molded

\footnotetext{
${ }^{48}$ Karol Wojtyla, "On the Metaphysical and Phenomenological Basis of the Moral Norm" in Person and Community: Selected Essays trans. by Theresa Sandok, OSM (New York: Peter Lang, 1993), 80. (Henceforth, MPBMN)

${ }^{49}$ Ibid., 90.

${ }^{50}$ Wojtyla, $A P, 163$.

${ }^{51}$ Ibid., 165.

(c) 2013 Jove Jim S. Aguas http://www.kritike.org/journal/issue 12/aguas june2013.pdf ISSN 1908-7330 
within the personal dimension, are followed by the sense of duty. ${ }^{52}$

\section{Synthesis}

There are always two aspects of an ethical or moral theory, the subjective and objective. The subjective points to the (subjective or personal) experience of man of a value, that is, value of those things or objects that he consider valuable. Value is considered good; hence, the good is instantiated by those objects one considers to be valuable. The will as an appetite is oriented or tends towards those objects that are valuable or good. Consequently, the good or the valuable object becomes the intentional object of one's willing. But the apprehension or appreciation of the good or valuable cannot be reduced to the mere personal assessment or feeling of the subject or the individual person. There must be an objective basis for evaluating or judging the real goodness or value of the intended object. Otherwise, it could lead to subjectivism. There is where a norm comes in as the objective basis of value or good. Norms are crucial in an ethical theory that purports to objectify the subjective aspect of morality. The norms serve as the basis of the truth of the good or value. While the good is object of the will, truth is the object of reason and it is the function of reason to objectify the truth. Truthfulness is an objective feature of the good and of the value; the good or the value cannot be good or valuable only for the person, it must be a real or true good or objective value.

Morality, however, is not only about value and good; morality properly speaking, refers to human action, and human action has this constitutive element of efficacy. Efficacy refers to the experience of the person as an agent or cause of an action. Wojtyla clarifies that while there are functions and activations that my happen in man, only those acts that originates from his efficacy can be considered either moral or immoral.

The efficacious acts are related to one's willing; they are also acts of the will or products of one's volition. In volition the will directs its attention towards a desirable object as an end or value. Hence, the will "transcends" itself towards the object. Here the moment of decision and choice are essential parts of willing; they define the intrinsic essence of volition as intentional acts. The ability to choose confirms the independence of the will in the act of willing. In choosing, the will is not cramped by the object or by the value as its end; it is the will and only the will that determines the object. The ability to decide and to choose is connected with the truth; the will has reference to truth. The will wants true goods, not things that appear to be good and are really not. To choose does not simply mean turning toward one value and away from others, but making a decision according to the

${ }^{52}$ Ibid.

(c) 2013 Jove Jim S. Aguas

http://www.kritike.org/journal/issue_12/aguas june2013.pdf

ISSN 1908-7330 
principle of truth. Choice and decision are preconditioned by knowledge of the truth.

Because the will wants the true good, then it must choose or do the true good; it must perform the true good act. It is here that duty comes in; in conscience, truth presents itself as the source of moral duty. The proper place of the subordination of the good to the truth is conscience. In conscience, the human act becomes the willing and choosing of a "true good." Through its first principle: "do good, avoid evil," conscience directs the person to choose and will the good, to go beyond the self and somehow rise above the self in the direction of the truth and in the direction of a good willed and chosen in the light of truth. The normative power of truth lies in duty, in the transition from the "be" to the "should."

Finally, morality is at the base of man's fulfillment. The person fulfills himself when he performs an action that is good, a true good, a good that is in accord with a true and good conscience. ${ }^{53}$ When the object of choice is a true good, then the human action is good and when the object of choice is a false good then the human action is bad or evil. ${ }^{54}$ The human person consequently becomes good or evil, depending on the morality of his actions. ${ }^{55}$ So the moral value of the act reaches the very depths of the human person. Self-fulfillment depends on the fulfillment or performance of a truly good act. When man performs an acts, he at once actualizes himself in the action, and as a human person, he becomes either good or evil depending on the moral value of the act performed. It follows that truth and goodness have a decisive influence on the formation of the subject and the total development of the person as revealed through the analysis of conscience and morality. ${ }^{56}$ In particular, the moral formation of the human person means a formation through moral good; the human person is formed through moral good.

Department of Philosophy, University of Santo Tomas, Philippines

${ }^{53} \mathrm{~A}$ true and good conscience is a conscience that judges an act in accord with its objective moral value, so that it judges an objectively good act as good and an objectively evil act as evil.

${ }^{54}$ Karol Wojtyla, "Human Nature as the Basis of Ethical Formation" in Person and Community: Selected Essays trans. by Theresa Sandok, OSM (New York: Peter Lang, 1993), 98.

${ }^{55}$ In another essay he wrote that beings are "goods" but human beings are have moral goodness, so as beings of a rational nature, in order for us to be goods in keeping with this nature, it is not enough for us to be physically good, but we must also and above all be morally good. Wojtyla, MPBMN, 88-89.

${ }^{56} \mathrm{Ibid} ., 236$.

(c) 2013 Jove Jim S. Aguas

http://www.kritike.org/journal/issue 12/aguas june2013.pdf

ISSN 1908-7330 


\section{References}

Aguas, Jove Jim, "Karol Wojtyla on the Integration of the Person" in Ad Veritatem: Multi-Disciplinary Research Journal of the UST Graduate School, 9:2 (March, 2010), 583-614.

Bloch, Alfred \& Czuczka, George eds., Wojtyla: Toward a Philosophy of Praxis (New York: Crossroad, 1981).

Buttiglione, Rocco, Karol Wojtyla: The Thoughts of the Man Who Became Pope John Paul II (Grand Rapids Michigan: WB. Eerdams Publishing Co., 1997).

Cosby, John, The Selfhood of the Human Person (Washington DC: The Catholic University Press of America, 1996).

Kupczak, Jaroslaw O.P., Destined for Liberty (Washington DC: The Catholic University of America Press, 2000).

Lawler, Ronald, The Christian Personalism of John Paul II: The John Paul Synthesis (Chicago: Franciscan Herald Press, 1982).

Schmitz, Kenneth, At the Center of Human Drama (Washington DC: The Catholic University of America Press, 1993).

Shivanandan, Mary, Crossing the Threshold of Love (Washington: The Catholic University of America Press, 1999).

Simpson, Peter, On Karol Wojtyla (Belmont CA: Wadsworth/Thomson Learning, 2001).

Szostek, Andrezj, "Karol Wojtyla's View of the Human Person in the Light of the Experience of Morality" in Existential Personalism, vol. LX. Proceedings of the American Catholic Philosophical Association, ed. Daniel O. Dahlstrom（Washington D.C. ACPA, 1986), 5063.

Weigel, George, Witness to Hope: The Biography of John Paul II (New York: Harper Collins Publishers, Inc, 1999).

Williams, George Huntston, The Mind of John Paul IL Origins of His Thoughts and Actions (New York: The Seabury Press, 1981).

Wojtyla, Karol, The Acting Person, trans. by from Polish of the book Osoba $i$ Czyn, Andrzej Potocki, established in collaboration with Cardinal Wojtyla by Anna-Teresa Tymieniecka for publication in the Reidel Book Series Annalecta Husserliana (Dordrecht, Holland; Boston, USA; London, England: D. Reidel Publishing Co., 1979). , "Participation or Alienation?," in Anna-Teresa Tymieniecka ed., The Self and The Other: The Irreducible Element in Man, Annalecta Husserliana, vol. 6, (1977), 61-73. , "Subjectivity and the Irreducible in Man," in Anna-Teresa Tymieniecka ed., Annalecta Husserliana, 7 (1978), 107-114. 
, "The Intentional Act and the Human Act, that is Act and Experience," in Anna-Teresa Tymieniecka ed., Annalecta Husserliana, 5 (1976), 269-280.

, Evaluation of the Possibilities of Building Christian Ethics on the Principles of Max Scheler's System (Lublin: Catholic University of Lublin, 1959).

, Love and Responsibility, trans. by H.T. Willetts (New York: Farrar, Straus, Giroux, Inc., 1981).

,Person and Community: Selected Essays, trans. by Theresa Sandok, OSM (New York: Peter Lang, 1993). 